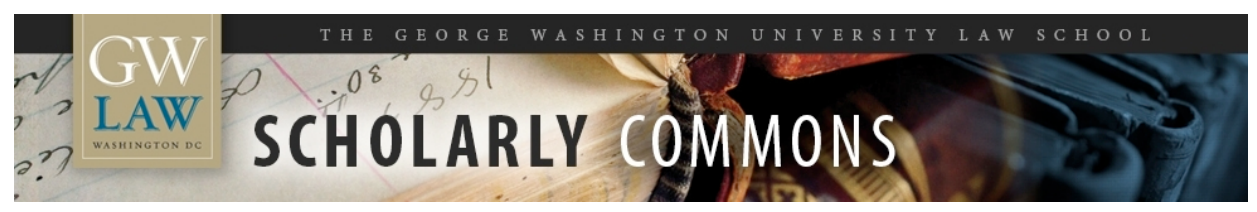

\title{
National Treatment in Copyright and Related Rights: How Much Work Does it Do?
}

Robert Brauneis

The George Washington University Law School, rbraun@law.gwu.edu

Follow this and additional works at: https://scholarship.law.gwu.edu/faculty_publications

Part of the Law Commons

\section{Recommended Citation}

Brauneis, Robert, "National Treatment in Copyright and Related Rights: How Much Work Does it Do?" (2013). GW Law Faculty Publications \& Other Works. 810.

https://scholarship.law.gwu.edu/faculty_publications/810

This Article is brought to you for free and open access by the Faculty Scholarship at Scholarly Commons. It has been accepted for inclusion in GW Law Faculty Publications \& Other Works by an authorized administrator of Scholarly Commons. For more information, please contact spagel@law.gwu.edu. 


\section{National Treatment in Copyright and Related Rights: How Much Work Does it Do?}

\section{Robert Brauneis*}

The obligation of national treatment makes an appearance in all five of the major active multilateral treaties concerning copyright and related rights, including the Berne Convention, ${ }^{1}$ the Rome Convention, ${ }^{2}$ the TRIPS Agreement, ${ }^{3}$ the WIPO Copyright Treaty ("WCT"), ${ }^{4}$ and the WIPO Performances and Phonograms Treaty ("WPPT"), a group I will collectively call the "five CRR treaties." The national treatment principle has been praised in part for its administrative convenience: it "allows [a treaty] member and its courts to apply their own law - the law they are familiar with." ${ }^{\prime \prime}$ Yet it is principally lauded for its substantive bite, as a rule requiring

* Professor of Law and Co-Director of the Intellectual Property Law Program, The George Washington University Law School; Member, Managing Board, Munich Intellectual Property Law Center. I would especially like to thank Marketa Trimble for her comments. For answering various queries I had, I would like to thank Steve Charnovitz, Josef Drexl, and Jane Ginsburg. For inspiring me to write this article through an invitation to the $14^{\text {th }}$ EIPIN Congress at the Maastricht University, I would like to thank Anselm Kamperman-Sanders.

${ }^{1}$ Berne Convention for the Protection of Literary and Artistic Works, Sept. 9, 1886, as revised at Paris on July 24, 1971 and amended on September 28, 1979, S. Treaty Doc. No. 99-27 (1986) [hereinafter Berne Convention], Arts. 5(1), 5(3).

${ }^{2}$ International Convention for the Protection of Performers, Producers of Phonograms and Broadcasting Organisations (Rome, 26 Oct. 1961) 496 U.N.T.S. 43, entered into force 18 May 1964 (hereinafter Rome Convention], Arts. 2, 4, 5, 6.

3 Agreement on Trade-Related Aspects of Intellectual Property Rights (Marrakesh, Morocco, 15 April 1994), Marrakesh Agreement Establishing the World Trade Organization, Annex 1C, 1869 U.N.T.S. 299, 33 I.L.M. 1197 (1994) [hereinafter TRIPS Agreement], Art. 3.

${ }^{4}$ WIPO Copyright Treaty, Dec. 20, 1996, 36 I.L.M. 65 (1997) [hereinafter WCT], Art. 3.

${ }^{5}$ WIPO Performances and Phonograms Treaty, Dec. 20, 1996, 36 I.L.M. 76 (1997) [hereinafter WPPT], Art. 4.

This article will not consider the Universal Copyright Convention in detail, but it also contains a national treatment obligation. See Universal Copyright Convention, Sept. 6, 1952, as revised at Paris on July 24, 1971, 943 U.N.T.S. 178 [hereinafter UCC], Art. II. The Geneva Phonograms Convention is the one treaty that might be considered a major multilateral convention concerning copyright or related rights but that does not contain a national treatment obligation. See Convention for the Protection of Producers of Phonograms against Unauthorized Duplication of their Phonograms (Geneva, 29 Oct. 1971) 866 U.N.T.S. 67, entered into force 18 April 1973.

${ }^{6}$ Ulrich Loewenheim, The Principle of National Treatment in the International Conventions Protecting Intellectual Property, in Patents and Technological Progress in a Globalized World: Liber Amicorum Joseph Straus 593, 593 (Wolrad Prinz zu Waldeck und Pyrmont, Martin J. Adelman, Robert Brauneis, Josef Drexl \& Ralph Nack, eds. 2009); see 1 Sam Ricketson \& Jane C. Ginsburg, International Copyright 
that treaty parties extend protection to non-nationals on the same terms as they do to their own nationals. It is that bite that commentators have in mind when they suggest that the "fundamental principle of the [Berne] Convention was national treatment," or that " $[\mathrm{t}]$ he national treatment and MFN principles are cornerstones of the WTO legal system, including TRIPS." ${ }^{8}$

Behind that sweeping rhetoric, however, there are reasons to question whether the national treatment obligations imposed by the five CRR treaties remain of paramount importance in practice. Together, those treaties now contain far more specific substantive minimum guarantees than the Berne Convention did in its first incarnation in 1886. They also contain a variety of specific exceptions and limitations to national treatment, from the "Rule of the Shorter Term" in the Berne Convention ${ }^{9}$ to the limitation of the national treatment obligation in the area of related rights to the specific rights granted in the applicable treaties. ${ }^{10}$ At the same time, the choice-of-law framework in which "national treatment" may have meant more than nondiscrimination has been substantially transformed. ${ }^{11}$ Thus, to the extent that countries are compelled by treaty to grant nationals of other parties specific rights to specific works or productions, and that the laws of those countries do not offer further protection, the remaining non-discrimination obligation has little room to operate as an independent constraint. ${ }^{12}$ Perhaps as a result, statistics about proceedings under the WTO Dispute Settlement Procedure suggest that the national treatment principle is far more important in the context of internal regulation and taxation of goods under the General Agreement on Tariffs and Trade ("GATT") intellectual property under the TRIPS Agreement. While national treatment has

and Neighbouring Rights: The Berne Convention and Beyond (hereinafter "Ricketson \& Ginsburg") \$ 6.73 (2d ed. 2005) (national treatment "has clear practical advantages, as it means that national courts have only to apply their own laws").

${ }^{7}$ Stephen P. Ladas, I The International Protection of Literary and Artistic Property 83 (1938); see Gail E. Evans, TRIPs and the Sufficiency of the Free Trade Principles, 2 J, World Intellectual Prop. 707, 711 (2005) ("The cornerstone of the Great Conventions of the latter Nineteenth Century was the principle of national treatment").

${ }^{8}$ UNCTAD/ICTSD Project on IPRs and Sustainable Development, Resource Book on TRIPS and Development 26 (2005)

${ }^{9}$ See infra text accompanying notes 144-145.

${ }^{10}$ See infra text accompanying notes 119-125. In addition, non-discrimination obligations that may apply to copyright and other intellectual property rights have been incorporated into more general human rights treaties, thus rendering the specific copyright treaty provisions less important. See, e.g., Dr. Silke von Lewinski, Intellectual Property, Nationality, and Non-Discrimination, http://www.wipo.int/edocs/mdocs/tk/en/wipo_unhchr_ip_pnl_98/wipo_unhchr_ip_pn 1_98_6.pdf.

${ }^{11}$ See infra text accompanying notes 146-147.

${ }^{12}$ See Evans, supra note 7, at 714-15 ("National treatment, by reference to a body of substantive law so extensive that it effectively codifies the law, appears to be a contradiction in nature."). Of course, unless treaties contain exhaustive rules concerning remedies and procedures (and the five CRR treaties don't), national treatment would still have a role to play.

13 See General Agreement on Tariffs and Trade, Oct. 30, 1947, 55 U.N.T.S. 194 [hereinafter "GATT 1947"], Art. III. 
featured in over 200 GATT complaints, it has featured in fewer than 20 TRIPS complaints. ${ }^{14}$ Of the only three Dispute Settlement Body decisions finding violations of national treatment under TRIPS (two of them involving the same law), none involved copyright or related rights. ${ }^{15}$

How might we assess the continuing impact of the principle of national treatment in the fields of copyright and related rights? In practice, the impact of national treatment may be limited on three different levels. First, the relevant treaties themselves may limit the scope of operation of national treatment. The treaties may contain explicit exceptions to national treatment; their structure may limit the operation of the national treatment rule; and they may contain substantive minimum requirements that limit the potential impact of national treatment. Second, countries may or may not offer copyright protection that exceeds minimum requirements imposed by treaties, and if additional protection is offered, it may be offered by many countries, thus limiting the divergence of a national treatment rule from that of a rule material reciprocity. Third, the value of literary and artistic works imported into one country from another may be relatively small, thus limiting the economic impact of granting broader protection to those works.

It cannot be within the scope of this article to consider exhaustively all three potential layers of limitation. Consideration of the second layer would require a comparison of the copyright laws of all Berne Union members, and consideration of the third would require empirical data about the value of literary and artistic works transmitted across the borders of all Union members. This article will, however, attempt to consider the first layer reasonably thoroughly, and the second and third layers anecdotally. Part I will consider several aspects of the form of the national treatment rule in the context of copyright and related rights, and of intellectual property more generally. Part II will consider the principal issues concerning the scope of application of the national treatment rule in the five CRR treaties. Part III will offer some concluding remarks. Among the conclusions will be that although national treatment continues to play an interstitial role in specific legal areas, its most important function may be as a symbolic carrier of the spirit of internationalism, a spirit that may be facing challenges as much from cultural preservationism as from economic protectionism.

\section{The Form of the National Treatment Principle in Treaties}

${ }^{14}$ For statistics about proceedings under the Dispute Settlement Understanding, see Henrik Horn and Petros C. Mavroidis, The Dispute Settlement Dataset (January l, 1995 - November 6, 2011), available at http://econ.worldbank.org/WBSITE/EXTERNAL/EXTDEC/EXTRESEARCH/0,,conte ntMDK:20804376-pagePK:64214825-piPK:64214943-theSitePK:469382,00.html.

${ }^{15}$ For the three decisions finding violations of TRIPS national treatment obligations, see Appellate Body Report, United States - Section 211 Omnibus Appropriations Act of 1998, WT/DSl76/AB/R (January 2, 2002) (adopted Feb. 1, 2002); Panel Report, European Communities - Protection of trademarks and Geographic Indications for Agricultural Products and Foodstuffs (Complaint of the United States) [hereinafter EG CIs - US], WT/DS174/R (March 15, 2005) (adopted April 30, 2005); and Panel Report, European Communities - Protection of trademarks and Geographic Indications for Agricultural Products and Foodstuffs (complaint of Australia) [hereinafter EG CIs - Australia], WT/DS290/R (March 15, 2005) (adopted April 30, 2005). 


\section{Affecting Copyright and Related Rights}

This Part will address several aspects of the form of the national treatment rule in copyright treaties and in intellectual property treaties more generally. These include the issues of the objects of the national treatment obligation; of whether the obligation is of a de jure or de facto nature; and of the potential difference between "equal" and "no less favorable" treatment.

\section{A. National Treatment's Protected Classes: Of Persons, Performances, Phonograms, Broadcasts}

The national treatment provisions in four of the five CRR treaties address discrimination against persons, natural or legal, on the basis of their nationality. That sets them apart from GATT, which addresses discrimination against imported products. ${ }^{16}$ The oldest of them, Article 5(1) of the Berne Convention, is framed in terms of discrimination against authors. It provides that, with respect to protected works outside their country of origin, covered "[a]uthors shall enjoy . . . the rights which th[e] respective laws [of Berne Union members] do now or may hereafter grant to their nationals." ${ }^{\text {17 }}$ Article III of TRIPS similarly requires each Member to "accord to the nationals of other Members treatment no less favourable than that it accords to its own nationals with regard to the protection of intellectual property." The WCT simply incorporates the national treatment provisions of the Berne Convention, ${ }^{18}$ while the WPPT requires its Contracting Parties to "accord to nationals of other Contracting Parties ... the treatment it accords to its own nationals." ${ }^{19}$

Only the Rome Convention explicitly constructs its national treatment guarantee by referring to criteria beyond the nationality of protected classes of persons. In the case of performers, for example, Article 2(l)(a) of the Rome Convention provides that the level of treatment guaranteed is not just that which Contracting States accord to performers that are its own nationals, but that which Contracting States accord to such performers "as regards performances taking place, broadcast, or first fixed, on its territory." ${ }^{20}$ In other words, with respect to nonnationals protected under the Convention, Contracting States cannot discriminate against performances that took place, were broadcast, or were first fixed in a foreign country, any more than they can discriminate on the basis of the performer's nationality. Similarly, the Rome Convention guarantees to protected non-national producers of phonograms the level of protection accorded to domestic producers for the phonograms that they first fixed or published domestically, ${ }^{21}$ and to protected non-national broadcasting organizations the level of protection accorded to

\footnotetext{
${ }^{16}$ See GATT 1947, Art. III.

${ }^{17}$ Berne Convention Art. 5(1). Article 5(3) of the Berne Convention closes what would otherwise be a loophole in the prohibition of discrimination against foreign authors by requiring national treatment within the country of origin if the author of the work at issue is not a national of that country. See Berne Convention Art. 5(3).

${ }^{18}$ See WIPO Copyright Treaty Art. 3.

${ }^{19}$ WIPO Performances and Phonograms Treaty Art. 4.

${ }^{20}$ Rome Convention Art. 2(1)(a).

${ }^{21}$ Rome Convention Art. 2(l)(b).
} 
broadcasters with domestically located headquarters for the broadcasts that they transmitted from domestically located transmitters. ${ }^{22}$

\section{B. Protection Against De Jure or De Facto Discrimination, and At What Level?}

The structure of the national treatment provisions under the five CRR treaties invites the question whether those provisions protect only against laws that explicitly treat non-nationals (and in the case of the Rome Convention, specified activities with foreign locations) unequally - what is sometimes called de jure discrimination - or also against laws that reach some level of unequal impact on nonnationals - de facto discrimination.

1. Close proxies. Although there is no case law under the Berne or Rome Conventions or the WIPO Internet Treaties that addresses the form of protection under their national treatment guarantees, one can imagine that discrimination on the basis of close proxies of nationality could be prohibited as obvious attempts at circumvention, even without fully embracing a de facto approach. Thus, for example, a law offering higher levels of copyright protection to residents than to non-residents should run afoul of national treatment obligations, even though some non-nationals may be residents and some nationals non-residents. ${ }^{23}$ Similarly, discrimination against a work on the basis of foreign first publication - offering higher protection to works first published domestically than those first published in the territories of other treaty members - should also run afoul of national treatment obligations, though nationals will sometimes first publish abroad and non-nationals domestically. ${ }^{24}$

2. TRIPS and "Effective Equality of Opportunities." In the three proceedings in which the WTO Dispute Settlement Body has found a violation of the TRIPS national treatment obligation, panel and appellate body reports have adopted a more thoroughgoing de facto approach to that obligation, based on case law under GATT 1947. In United States - Section 211 Omnibus Appropriations Act of 1998, both the Panel and the Appellate Body decided that the appropriate standard to apply under Article 3.1 of TRIPS was whether a measure provided "effective equality of opportunities as between [nationals and non-nationals] in respect of protection of intellectual property

${ }^{22}$ Rome Convention Art. 2(1)(c).

${ }^{23}$ Both the Berne Convention and TRIPS recognize and reinforce the close relationship between residency and nationality. Thus. For example, the Berne Convention provides that "[a]uthors who are not nationals of one of the countries of the Union but who have their habitual residence in one of them shall, for the purposes of this Convention, be assimilated to nationals of that country." Berne Convention Art. 3(2). TRIPS provides that the term "nationals" includes, in the case of a separate customs territory, persons who are domiciled in that territory. See TRIPS Art. 1(3), fn. 1; Panel Report, Panel Report, EG CIs - US, I I7.163 - 7.167194, WT/DS174/R (interpreting "separate customs territory" to include only subdivisions of countries, and not the European Community).

${ }^{24}$ The Rome Convention explicitly prohibits discrimination against phonograms on the basis of their foreign publication. See Rome Convention Art. 2(l)(b). That might lead some to argue that the absence of such an explicit prohibition in the other CRR treaties means that they must allow such discrimination, but application of such a canon across different treaties is dubious at best. 
rights." ${ }^{25}$ That standard was drawn from a decision under the GATT 1947 treaty, which held that "[t] he words 'treatment no less favourable' in paragraph 4 [of Article III of GATT 1947] call for effective equality of opportunities for imported products in respect of the application of laws, regulations and requirements affecting the internal sale, offering for sale, purchase, transportation, distribution or use of products. ${ }^{26}$

The Section 211 proceeding involved a United States federal law that distinguished on its face between US nationals and nationals of other countries, and the Reports in that case therefore did not have occasion to consider how the "effective equality of opportunity" standard might be applied to a measure that did not facially distinguish on the basis of nationality. Such an occasion was provided in the two proceedings involving the European Communities Regulation on the protection of geographical indications ("GIs"). That Regulation created Community-wide protection for registered GIs, but imposed additional burdens on registration of GIs for areas outside of the EC, and as interpreted by the Dispute Settlement Panels, effectively required reciprocal protection by the non-EC countries where such areas would be located. The EC argued that such disadvantages did not violate the TRIPS Art. 3.1 national treatment obligation because they accorded formally identical treatment to nationals and non-nationals, since they were based on the location of the area covered by a GI registration rather than the nationality of the applicant. The Panel appointed in both proceedings rejected that argument, however, and concluded that the distinctions drawn by the Regulation closely aligned with nationality. That panel found that "the vast majority of natural and legal persons who produce, process and/or prepare products according to a GI specification within the territory of a WTO Member party to this dispute will be nationals of that Member," ${ }^{27}$ and that "the GIs for which nationals of other WTO Members would wish to obtain protection are overwhelmingly located outside the European Communities." 28

Exactly what degree of disparate impact, or of alignment between nationality and a challenged law's classification, must be shown to establish a TRIPS Article 3 violation, is an open question, as is the degree to which a country's reasons for adopting a provision independent of favoring nationals should be taken into account. ${ }^{29}$

${ }^{25}$ Panel Report, United States - Section 211 Omnibus Appropriations Act of 1998, I 8.131, WT/DS176/R (August 6, 2001), see Appellate Body Report, United States Section 211 Omnibus Appropriations Act of 1998, I 258, WT/DS176/AB/R (January 2, 2002) (adopted Feb. 1, 2002) (agreeing with the Panel Report that a measure " could be considered to provide a less favourable treatment to nationals of other Members as it denies effective equality of opportunities" to non-United States nationals in the United States ").

${ }^{26}$ Panel Report, United States-Section 337 of the Tariff Act of 1930, I 5.1l, BISD 36S/345 (adopted November 7, 1989).

${ }^{27}$ Panel Report, EG CIs - US, I 7.194, WT/DS174/R; Panel Report, EC GIs - Australia, 97.230, WT/DS290/R

${ }_{28}$ Panel Report, EG CIs - US, I 7.196, WT/DSI74/R; Panel Report, EC GIs - Australia, I7.232, WT/DS290/R.

${ }^{29}$ Professors Graeme Dinwoodie and Rochelle Dreyfus have argued that national treatment analysis under TRIPS should inquire more directly into the motivation for adopting particular provisions, because a variety of non-discriminatory motives should be considered consistent with TRIPS. See Graeme B. Dinwoodie \& Rochelle C. 
One classification within the realm of copyright and related rights that might require further exploration of those questions is that of literary works distinguished on the basis of the language in which they are written. Some public lending right schemes, for example, offer benefits for works written in or translated into one language, typically the national language, but not for those written in or translated into other languages. ${ }^{30}$ To be sure, in many cases there will be a strong correlation between language and nationality - for example, most authors writing in or translating into or from Swedish are probably Swedish nationals. ${ }^{31}$ The government of Sweden, however, would argue that it has an interest in making materials available in Swedish that is independent of the differential benefits that the scheme may end up providing to Swedish nationals: it would be delighted, no doubt, if many non-Swedish nationals began to write in Swedish. Moreover, it would be strange if some language-based schemes survived TRIPS Article 3 scrutiny because many non-nationals wrote in the national language - France, for example, could point to Belgians, Swiss, Canadians, Moroccans and others who wrote in French - while other identical schemes were struck down because fewer non-nationals wrote in the national language.

Once one holds that de facto discrimination is prohibited by a national treatment guarantee, it appears to be tempting to hold that it is always the impact of the scrutinized provision that matters, and thus that even explicit "de jure" legal distinctions on the basis of nationality will not automatically run afoul of national treatment. Thus, its 2001 decision in Korea - Various Measures on Beef, $f^{32}$ the WTO Appellate Body held that measures that formally treated nationals and non-nationals differently did not automatically violate the national treatment obligation in Article III.4. of GATT:

A formal difference in treatment between imported and like domestic products is ... neither necessary, nor sufficient, to show a violation of Article III:4. Whether or not imported products are treated "less favourably" than like domestic products should be assessed instead by examining whether a measure modifies the conditions of competition in the relevant market to the detriment of imported products. ${ }^{33}$

Dreyfus, A Neofederalist Vision of TRIPS: The Resilience of the International Intellectual Property Regime 100-102 (2012)

${ }^{30}$ For comparative documentation of existing public lending right programs, seePLR International, Established PLR Regimes, http://www.plrinternational.com/established/established.htm.

${ }^{31}$ The Swedish public lending right scheme covers literary works written in Swedish, translations to or from Swedish and books written in foreign languages by authors permanently residing in Sweden. See http://www.plrinternational.com/established/plradministrators/sweden.htm. Exactly how the inclusion of all permanent residents in the scheme should affect the national treatment analysis, and whether that provision could be found severable, are open questions.

${ }^{32}$ Appellate Body Report, Korea - Measures Affecting Imports of Fresh, Chilled and Frozen Beef, WT/DS161/AB/R, WT/DS169/AB/R (adopted January 10, 2001).

${ }^{33}$ Id. at $\mathbb{I} 137$. 
Two final comments on the national treatment obligation under copyright treaties. First, the economic and cultural interests that benefit from national treatment violations under copyright treaties may be different than those benefiting from national treatment violations involving goods under GATT. Differential overregulation or overtaxation of imported products will presumably increase their cost, thus harming domestic consumers and benefiting domestic producers. By contrast, differential underprotection of foreign authors is likely to reduce the cost of consuming their works, thus benefiting domestic consumers and harming domestic authors. ${ }^{34}$ Analogously, a U.S. International Trade Commission study estimated that the Uruguay Round Agreements, by lowering barriers to trade in goods, would harm U.S. textile producers and reduce textile prices for U.S. consumers, ${ }^{35}$ at the same time, by strengthening intellectual property protection, they would benefit U.S. manufacturers of recorded media (encompassing computer software, sound recordings, and videos) and raise prices for consumers of that media. ${ }^{36}$ However, some schemes that arguably violate the national treatment obligation in copyright and related rights are more likely to harm domestic consumers and benefit domestic producers. One example that is discussed further below is a tax on all movie tickets the proceeds of which are distributed solely to domestic movie producers

Second, it is not clear that either GATT or TRIPS national treatment analysis is equipped to deal with a situation in which an entire broad category of goods or works of authorship is primarily produced abroad, and the entire category is regulated, taxed or underprotected with the goal of improving domestic balance of trade. Suppose, hypothetically, that $95 \%$ of perfumes and other fragrances are produced abroad, and 5\% domestically. A tax on all fragrances will then primarily burden non-nationals, and will likely reduce consumption of foreign goods if consumer spending is diverted to a range of other goods that are on average more likely to be produced domestically. Yet if consumers, faced with high perfume prices, end up buying a wide variety of other goods - some buy flowers for presents instead, others buy chocolates or leather goods or liquor - it is not clear that any of those others can be considered "like goods" for purposes of performing GATT national treatment analysis. Similarly, if perfumes were largely formulated abroad but often imitated domestically, it is not clear that under current TRIPS Article 3 analysis the refusal to consider the original formulation "authorship" and the scent a copyrightprotected work would be considered a violation of the obligation to treat nationals of other WTO members "no less favorably" than a country's own nationals.

\section{Equal Treatment vs. "No Less Favorable" - In Some Respects a False Dichotomy}

It may appear that some copyright treaties, such as the Berne Convention, guarantee foreign authors treatment equal to domestic authors, whereas others, such as TRIPS, guarantee a different level of treatment, namely treatment "no less favorable than" domestic authors. However, this different wording is in at least some respects likely not to result in a difference in practice. Suppose, for example, that a law

\footnotetext{
${ }^{34}$ In both cases, the benefitted parties might be reversed in the long run if the regulation or refusal to extend protection were part of a strategy to demand reciprocal treatment from foreign countries.

${ }^{35}$ See I United States International Trade Commission, Potential Impact on the U.S. Economy and Industries of the GATT Uruguay Round Agreements, Investigation No. 332-353, at IV-9 (1994).

${ }^{36}$ See id. at VII-18 - VII-19.
} 
restored copyright in works of foreign authors that had fallen into the public domain for lack of compliance with formalities, but did not restore copyright in such works of domestic authors. ${ }^{37}$ Such a law does not treat foreign authors less favorably that domestic authors, and hence does not violate TRIPS, but it clearly does not treat foreign and domestic authors equally. However, domestic authors could not claim a violation of Berne national treatment, because they are not beneficiaries of that provision, or indeed of the entire Convention. At the same time, foreign authors, unable to show any injury from having their copyrights restored while those of domestic authors had not been, should not be able to claim a violation of Berne national treatment either. Thus, such a case should turn out no differently under Berne than under TRIPS.

It may be that the TRIPS national treatment provision would be interpreted to encompass a broader range of de facto disparate impact violations than the Berne provision. Although TRIPS Article 3 is explicitly limited by the national treatment exceptions enumerated in the treaties it incorporates ${ }^{38}$ it does not seem that it would be limited by the form of national treatment obligation in an incorporated treaty with respect to rights covered by that treaty. In other words, the TRIPS Article 3 national treatment guarantee with respect to intellectual property, including copyright, is independent of the Berne Convention Article 5 guarantee, and apart from the specific Berne exceptions it incorporates, follows its own form, which may include greater de facto analysis than Berne Article $5 .{ }^{39}$

\section{The Scope of the National Treatment Principle in Treaties Affecting Copyright and Related Rights}

This article now turns to the issue of the scope of application of the national treatment rules discussed in Part I. This Part will consider several of the principal issues of scope of application, including the works or other productions to which the rules apply, the rights subject to the rules, remedies, acquisition of rights, term, and ownership.

A. Subject-matter: Works or Productions

to Which National Treatment Obligations Apply

With respect to the subject matter protected by a national treatment guarantee, the provisions of the five CRR treaties are partially but not entirely

${ }^{37}$ Cf. 17 U.S.C. $\$ 104$ A (restoring copyright in certain works under somewhat more complicated terms than those posed hypothetically in the text).

${ }^{38}$ See TRIPS Art. 3(1) (providing that the Article 3 national treatment guarantee is "subject to the exceptions already provided in, respectively, the Paris Convention (1967), the Berne Convention (1971), the Rome Convention or the Treaty on Intellectual Property in Respect of Integrated Circuits.").

39 Of course, TRIPS also incorporates the Berne Article 5 national treatment obligation. See TRIPS Art. 9 (incorporating Articles 1 through 21 of the Berne Convention (1971) and the Appendix thereto, excepting Article 6bis). Thus, if the Berne Article 5 obligation were found to prohibit some provisions that the TRIPS Article 3 obligation did not - say, formally different treatment that did not deny effective equality of opportunity - those provisions could also amount to a violation of TRIPS that could theoretically result in the authorization of sanctions. It is not clear what those sanctions would be, however. 
independent of each other. The Berne Convention defines the subject matter to which it applies in Article 2(1). TRIPS and the WCT both incorporate that provision, and both also contain two provisions that at least clarify and arguably expand Berne Convention subject matter. Neither TRIPS nor the WPPT incorporate the Rome Convention provisions defining protected subject matter, but they identify subject matter that is congruent with Rome Convention subject matter.

1. Literary and Artistic Works: Berne and its Incorporation into TRIPS and the WCT. The Berne Convention identifies its subject matter both by providing a general definition of a term and by enumerating specific examples that it states are not-exclusive. The general term is "literary and artistic works," defined as "including every production in the literary, scientific and artistic domain, whatever may be the mode or form of its expression." ${ }^{30}$ That definition is followed by an enumeration of many more specific examples of covered types of works - from books to cinematographic works and architecture. $^{41}$

It is clear that specifically listed or enumerated works must be protected by Berne Union members, and are subject to obligations regarding the absence of formalities, substantive minimums, and national treatment. Article 2(6) provides that "[t]he works mentioned in this Article shall enjoy protection in all countries of the Union," ${ }^{42}$ Article 5(1) requires Union members to grant authors "in respect of works for which they are protected under this Convention" both national treatment and the specific minimum protections recognized in the Convention, and Article 5(2) provides that enjoyment of such rights "shall not be subject to any formality."

The obligations with regard to unenumerated literary and artistic works are less clear, as is the nature of the line separating literary and artistic works from other productions that would not qualify as literary and artistic works. The enumeration of literary and artistic works in Article 2(1) is structured to be non-exclusive, preceded as it is by the phrase "such as." ${ }^{43}$ Most commentators, however, take Article 2(6)'s reference to "works mentioned in this Article" to mean specifically enumerated types rather than the overarching category of "literary and artistic works," 44 and conclude that the revision history of Berne suggests that Union members are not obligated to protect any types of works that are not enumerated. ${ }^{45}$

\footnotetext{
${ }^{40}$ Berne Convention art. 2(1)

${ }^{41}$ See id.

${ }^{42}$ Berne Convention Art. 2(6).

${ }^{43}$ See Berne Convention Art. 2(1).

${ }^{44}$ See 1 Ricketson \& Ginsburg $\$ 8.09$ ("It is of critical importance for a work to be included in the list in article 2(1) because article 2(6) . . puts it beyond doubt that such works are then to be protected under the Convention."); Silke von Lewinski, International Copyright Law and Policy $\$ 5.76$ (2008) (under Article 2(6), "only the works explicitly mentioned in Article 2(1), (3) and (5) of the Berne Convention must be protected by Union countries in the Berne context."); Wilhelm Nordemann, Kai Vinck, Paul Hertin \& Gerald Meyer, International Copyright and Neighboring Rights Law: Commentary with Special Emphasis on the European Community Art. 2/2bis BC n. 2 (1990) ("The list of individual categories of works in Art. 2 par. 1 is not exhaustive. But the right to protection under convention law is limited to this catalogue.")

${ }^{45}$ See, e.g., 1 Ricketson \& Ginsburg $\$ \$ 8.08,8.11$.
} 
If a Union member decides to protect a type of production that is not an enumerated work, two issues arise. First, is that type of production a "literary and artistic work"? If not, then the production falls completely outside of the scope of the Convention, and protection for that production need not meet any Convention requirements. Second, if a Union member extends protection to a production determined to be an unenumerated literary and artistic work, must its protection of that work comply with both Berne substantive minimums and the national treatment obligation, or only the latter?

a. The outer boundaries of "literary and artistic work." With regard to the first question, there are two principal schools of thought. Some commentators, such as Stephen Ladas ${ }^{46}$ and Sam Ricketson, ${ }^{47}$ have argued that the Berne Convention leaves it up to Union members to decide whether a particular type of unenumerated production is a literary and artistic work. According to those commentators, one must look to the treatment of the production in the Union member's own laws. If those laws treat a production as a literary and artistic work - if they include the production alongside Berne-enumerated works as copyrightable subject matter - then with respect to that country, the production is a "literary and artistic work" within the meaning of Berne. Under that approach, for example, because the United States treats sound recordings as copyrightable subject matter alongside literary works and other Berne-enumerated works, ${ }^{48}$ it must meet at least some Berne Convention obligations with respect to sound recordings. By contrast, countries such as France and Germany that do not group sound recordings with enumerated Berne works need not meet Berne obligations with respect to them.

The other school of thought insists that the Berne Convention itself provides a determinate answer to the question of whether a particular production counts as a "literary or artistic work," and that countries that group productions that are not Berne Convention literary or artistic works together with those that are do not have any Berne Convention obligations with respect to the former. Adherents of that school include Fritz Ostertag, ${ }^{49}$ Eugen Ulmer, ${ }^{50}$ and David Vaver. ${ }^{51}$ Thus, Vaver argues that "[a]uthor' in the [Berne Convention] implies a person who applies his/her personal creativity to produce a literary or artistic work." ${ }^{52}$ The text of the Berne Convention does not include such a definition, but with respect to collections of works (sometimes referred to as compilations), it does require protection to such collections which "by reason of the selection and arrangement of their contents,

${ }^{46}$ See Stephen P. Ladas, The International Protection of Literary and Artistic Property 266 (1938).

${ }^{47}$ See Sam Ricketson, The Law of Intellectual Property 914.22 (1984)

${ }^{48}$ See 17 U.S.C. \$ 102(a) (listing "sound recordings" as a category of works of authorship in which copyright subsists).

49 See Fritz Ostertag, La Protection des disques étrangers en Suisse, 53 Le Droit d'Auteur 41 (1940).

${ }^{50}$ See Eugen Ulmer, The "Droit de Suite" in International Copyright Law, 6 Int. Rev. of Intell. Prop. \& Comp. L. 12, 21 (1975).

${ }^{51}$ See David Vaver, The National Treatment Requirements of the Berne and Universal Copyright Conventions Part One, 17 Int. Rev. of Intell. Prop. \& Comp. L. 577, 590-597 (1986).

${ }^{52}$ Id. at 594. 
constitute intellectual creations, ${ }^{, 53}$ and one can argue that that provision makes explicit with regard to collections a requirement of "intellectual creation" that is implicit with respect to all literary and artistic works. ${ }^{54}$

Under that interpretation, some productions that are not enumerated in the Berne Convention would seem more likely to be found to be Berne Convention "literary and artistic works," whereas others would not. Contrast, for example, perfumes and databases. The Supreme Court of the Netherlands has ruled that the copyright law of the Netherlands protects perfumes. ${ }^{55}$ The creation of a perfume, as a particular olfactory experience, would seem to involve an exercise of personal creativity. There are no hard-and-fast rules for making a good perfume; the process involves the application of judgment to the creation of a product of aesthetic appeal. Moreover, the olfactory experiences can apparently be fixed stably enough and perceived subtly enough to be recognized as "the same" or "different" on different occasions. People will recognize Chanel No. 5 or Shalimar from bottles made years apart, an important condition for being recognizable as a "work." Thus, once a country recognizes copyright protection for perfumes, it is likely to be subject to Berne Convention obligations with respect to them. ${ }^{56}$

${ }^{53}$ Berne Convention Art 2(5).

${ }^{54}$ Paul Goldstein, joined by Bernt Hugenholtz in the third edition of his treatise, seems to take a hybrid position. He argues that some unenumerated productions will definitely fall within the definition of "literary and artistic works" and therefore be subject to Berne obligations whether or not a country extends protection to them under its copyright laws. See Paul Goldstein, International Copyright: Principles, Law and Practice 73-74 ( $1^{\text {st }}$ ed. 2001) (hereinafter "International Copyright ( $1^{\text {st }}$ ed.)"); Paul Goldstein \& Bert Hugenholtz, International Copyright: Principles, Law and Practice 102-103 ( $3^{\text {rd }}$ ed. 2013) (hereinafter "Goldstein \& Hugenholtz ( $3^{\text {rd }}$ ed.)"). Other unenumerated productions will not fall within that definition, but if a country nonetheless protects them in its copyright law, then they should be subject to the Berne national treatment obligation (but not to substantive minima). Goldstein argues that the latter conclusion is supported by considerations both of "economiz[ing] on line-drawing around rights and subject matter coming within the national treatment obligation" and of "deference to the legislature's motives in choosing to place the copyright label on that which, at lesser international expense, it could have called by another name." Paul Goldstein, International Copyright ( ${ }^{\text {st }}$ ed.) 74-75; Goldstein \& Hugenholtz ( $3^{\text {rd }}$ ed.) 103-104.

${ }^{55}$ See Lancôme/Kecofa, Hoge Raad der Nederlanden [HR] [Supreme Court of the Netherlands], 16 June 2006, NJ 585.

${ }^{56}$ In fact, in the Lancôme case, the Supreme Court of the Netherlands was recognizing protection for a foreign national, Lancôme, which was a company organized under French law. Because both the Netherlands and France are members of the European Union, the Netherlands would presumably have to extend protection of perfumes to French nationals under the non-discrimination principle of Article 18 of the Treaty of the Functioning of the European Union, regardless of whether the Berne Convention applied. See European Union, Consolidated version of the Treaty on the Functioning of the European Union, 13 December 2007, 2008/C 115/01, Art. 18; Phil Collins v.Imtrat Handelsgesellschaft GmbH, [1993] ECR I-5145, c 92/92 (October 20, 1993). Application of a rule of material reciprocity would result in denial of protection to Lancôme, since the Cour de Cassation in France has refused to recognize copyright protection for 
Both TRIPS and the WCT acknowledge that databases can be Berne Convention literary or artistic works. Building on the language applied by Article 2(5) of Berne to collections, TRIPS and the WCT declare that if "by reason of the selection or arrangement of their contents [databases] constitute intellectual creations, ${ }^{, 57}$ they must be protected as literary or artistic works. However, if a law protects databases regardless of any creative judgment involved in their creation, then those objects of protection are not Berne Convention literary or artistic works. The most prominent example of the latter type of protection is, of course, Article 7 of the European Database Directive, which grants protection to databases in which creators can show "qualitatively and/or quantitatively a substantial investment in either the obtaining, verification or presentation of the contents. ${ }^{58}$ The creations protected under that Article - all gatherings of information in which a substantial qualifying investment has been made - are quite clearly not "literary and artistic works," since principles of "intellectual creation," "authorship," or "creativity" do not define them. Therefore, they do not fall within the scope of the Berne Convention, and the Convention does not require the European Union to grant either substantive minima or national treatment to them. In fact, of course, the European Union does neither. It provides protection for a less-then-Berne-minimum of 15 years, ${ }^{59}$ and it provides protection to those who are neither nationals nor habitual residents of EU member states only by specific further agreement, thus contemplating a requirement of material reciprocity. ${ }^{60}$

To be sure, it will be difficult to determine whether some productions are Berne literary and artistic works by application of an abstract concept alone. In some cases, more concrete historical treatment will be relevant. David Vaver expresses the view that "performers, sound recorders, broadcasters and the like are neither 'authors' nor do they create literary and artistic works."'l Whether or not that is ultimately true or not - and I have argued that at least with regard to musical sound recordings and those who create them it is not ${ }^{62}$ - it does seem that those who participated in the diplomatic conferences in which the Berne Convention was drafted and revised believed it to be true, and that only such an interpretation explains the separate history of the Rome Convention.

Before TRIPS and the WCT, it was also difficult to figure out whether computer programs were Berne Convention literary works. The production of computer programs of any complexity does seem to involve creative judgment, but in many cases computer programs end up performing a function that has no expressive or aesthetic component: they may just regulate an industrial process or execute a

perfumes. See Beaute Prestige International v Senteur Mazal, Cour de Cassation (Case 0713952, July 1, 2008) (ruling that perfurmes not protected under French copyright law). ${ }^{57}$ TRIPS Art. 10(2); WCT Art. 5.

${ }^{58}$ Directive 96/9/EC of the European Parliament and of the Council of 11 March 1996 on the legal protection of databases, Art. 7.

${ }^{59}$ Id. Art. 10.

${ }^{60}$ Id. Art. 11.

${ }^{61}$ Id. at 594.

${ }^{62}$ See Robert Brauneis, Musical Work Copyright in the Era of Digital Sound Technology. 
commercial transaction. However, TRIPS and the WCT have resolved that issue, as they declare that computer programs will be treated as literary works under Berne. ${ }^{63}$

In the case of one type of production that falls at the borderline of the Berne concept of "artistic work" - industrial designs - the Convention itself provides specific directions, and a specific exception to national treatment. Article 2(7) of the Convention provides that "[w]orks protected in the country of origin solely as designs and models shall be entitled in another country of the Union only to such special protection as is granted in that country to designs and models; however, if no such special protection is granted in that country, such works shall be protected as artistic works." ${ }^{64}$ Thus, if Country A, a Berne Union country, decides to grant only sui generis protection to industrial designs, and not copyright protection, and Country B, also a Berne Union country, grants both sui generis and copyright protection for such works, then under Article 2(7) Country B does not have to grant works originating in Country A copyright protection, as it would otherwise have to under the principle of national treatment.

b. Non-Enumerated works under Berne: national treatment alone, or substantive minima as well? Some commentators, notably Ricketson \& Ginsburg ${ }^{65}$ and Nordemann et al., ${ }^{66}$ can be read as contending that protection of literary and artistic works not enumerated in Berne is subject only to the national treatment requirement, and not to the requirement of compliance with Berne substantive minima. That would provide a larger role for national treatment. Yet Silke von Lewinski has argued that protection of unenumerated literary and artistic works should be subject to the full set of Berne obligations, ${ }^{67}$ and indeed Article 5(1) accords national treatment and substantive minima protections in a single sentence, leaving little room for a textual argument that only national treatment would apply to unenumerated works. ${ }^{68}$ Thus, it is unclear

${ }^{63}$ See TRIPS Art. 10(1); WCT Art. 4.
${ }^{64}$ Berne Convention Art. 7.
${ }^{65}$ See 1 Ricketson \& Ginsburg $₫ 8.11$ ("In the absence of enumeration, if Union country A decides that a new category of work is a literary or artistic work entitled to protection under its own law, it is bound to accord the same protection to authors from other Union countries under the principle of national treatment ....").

${ }^{66}$ See Wilhelm Nordemann, Kai Vinck, Paul Hertin \& Gerald Meyer, International Copyright and Neighboring Rights Law: Commentary with Special Emphasis on the European Community Art. 2/2bis BC n. 2 (1990) ("For a new class of works that is no enumerated in the catalogue, the Union author can claim protection only on the basis of national treatment of Union authors, i.e., make a claim if national law already provides for such protection (Art. 19) ....")

${ }^{67}$ See Silke von Lewinski, International Copyright Law and Policy $\$ 5.76, \$ 5.76$ n. 14 (2008).

${ }^{68}$ See Berne Convention Art. 5(1). Nordemann et al. seem to suggest that Article 19 would provide a basis for claiming national treatment independent of Article 5, but this would most likely involve a misreading of Article 19. Article 19 makes it clear that Berne Union authors are not limited to claiming protection meeting the substantive minimums of Berne if the principle of national treatment required more, or if national law happened to extend greater protection to them even when it was not required to do so under the Convention. However, Article 19 does not itself seem to impose 
whether national treatment has additional importance with respect to unenumerated works to which Berne substantive minimum requirements might not apply.

2. Performances, Phonograms, and Broadcasts: the Rome Convention, TRIPS, and the WPPT. There has been less controversy over subject-matter coverage of the Rome Convention, TRIPS and the WPPT with respect to their national treatment obligations regarding performances, phonograms, and broadcasts, perhaps because their subject matter is defined more narrowly than "literary and artistic works." The Rome Convention defines "performers" as those who "perform literary and artistic works," ${ }^{69}$ and thus its guarantee of national treatment to performers does not extend to those performers whose performances are spontaneous or would not otherwise count as performances of literary and artistic works, such as clowns, acrobats, jugglers, and athletes performing in sporting events. ${ }^{70}$ The WPPT has a similar definition, but includes those who "perform literary or artistic works or expressions of folklore." ${ }^{71}$ The latter term sweeps in some performances that are not of fixed works with identifiable authors, but only a certain class of such performances - many performances of clowns, jugglers, and so on, involve neither literary and artistic works nor folklore. Phonograms, as fixations or representations of sounds not accompanied by images, seems to be a relatively well-defined category. ${ }^{72}$ While broadcasts are not

additional obligations on Berne Union members. See 1 Ricketson \& Ginsburg $\$ \$ \$ 6.81$, 6.82 (discussing the history of Article 19).

${ }^{69}$ Rome Convention Art. 3(a) (defining "performers" as "actors, singers, musicians, dancers, and other persons who act, sing, deliver, declaim, play in, or otherwise perform literary or artistic works"); see Rome Convention Art. 4 (granting national treatment to performers under certain conditions).

${ }^{70}$ Article 9 of the Rome Convention provides that "Any Contracting State may, by its domestic laws and regulations, extend the protection provided for in this Convention to artists who do not perform literary or artistic works." It is not clear, however, that a contracting state that did so would be required to provide national treatment, since the national treatment obligation of Article 4 only applies to "performers," not "artists who do not perform literary and artistic works."

${ }^{71}$ WPPT Art. 2(a) (emphasis added). "Folklore" is not defined in the WPPT; for a discussion of what might be included by that term, see II Ricketson \& Ginsburg \$ 19.40 .

${ }^{72}$ The Rome Convention defines "phonogram" as "any exclusively aural fixation of sounds of a performance or of other sounds." Rome Convention Art. 3(b). The WPPT defines "phonogram" as "the fixation of the sounds of a performance or of other sounds, or of a representation of sounds, other than in the form of a fixation incorporated in a cinematographic or other audiovisual work." WPPT Art. 2(b). The WPPT definition is possibly slightly broader, but the changes were made principally to accommodate new technologies, rather than to substantially broaden coverage. The "representation of sounds" clause was added to account for the possibility that phonograms can be created directly on recording media, using, for example, digital sound synthesis, without ever having to create sounds and then fix them through transduction. The WPPT also allows the possibility of sound to be fixed together with text (such as metadata in a digital file) or other data without ceasing to be a phonogram. 
covered by the WPPT, the Rome Convention defines broadcasting as "transmission by wireless means for public reception,"

\section{B. Rights: Of Protection Above Minimum Guarantees and Remunerations that May Not Be Rights}

1. Rights in Literary and Artistic Works: The Berne Convention and TRIPS. The obligation of national treatment in the Berne Convention, and in TRIPS as regards copyright, clearly extends to any rights that domestic law grants authors with respect to their literary and artistic works, in addition to those rights that are specifically required as substantive minimums of protection. Thus, for example, although neither Berne nor TRIPS requires parties to grant a general right of distribution, ${ }^{24}$ United States copyright law does grant such a right, ${ }^{75}$ and Berne and TRIPS then require the United States to extend that distribution right to non-nationals. Underlining this obligation, Article 5(1) of Berne explicitly requires national treatment, not only with respect to rights recognized at the time of accession to the Convention, but rights created in the future - it grants to protected authors with respect to protected works "the rights which their respective laws do now or may hereafter grant to their nationals." 76

The most obvious rights granted by many Union members that would seem to exceed Berne and TRIPS substantive minimums yet fall within national treatment are those included in the WCT. They include the "making available" right ${ }^{77}$ and the obligations concerning technological measures ${ }^{78}$ and rights management information. $^{79}$ Because these are indeed required by the WCT, national treatment would step in only with regard to nationals of those countries that are parties to Berne and/or TRIPS but not the WCT. As of this writing, however, there are still a significant number of such these. There are 76 countries that are members of Berne but not of the WCT, including countries such as Canada and India. ${ }^{80}$ Thus, only national treatment would require the United States and other Berne and TRIPS parties that have implemented the WCT domestically to accord to the works of a

\footnotetext{
${ }^{73}$ Rome Convention Art. 3(f).

${ }^{74}$ See Berne Convention Art. 14(1)(i) (granting a right of distribution in cinematographic works).

${ }^{75}$ See 17 U.S.C. \$106(3).

${ }^{76}$ Berne Convention Art. 5(1).

${ }_{77}^{73}$ See WIPO Copyright Treaty Art. 6(1).

${ }^{78}$ See WIPO Copyright Treaty Art. 11.

${ }^{79}$ See WIPO Copyright Treaty Art. 12(1).

80 See Contracting Parties > WIPO Copyright Treaty, http://www.wipo.int/treaties/en/ShowResults.jsp?lang=en\&treaty_id=16 (total contracting parties: 90); Contracting Parties > Berne Convention, http://www.wipo.int/treaties/en/ShowResults.jsp?lang=en\&treaty_id=15 (total contracting parties: 166).
} 
Canadian author like Robertson Davies ${ }^{81}$ or an Indian author like Arundhati Roy ${ }^{82}$ a "making available" right or a right against circumvention of technological measures. ${ }^{83}$

In this regard, it is important to note that Article 20 of the Berne Convention should not be interpreted to create an exception to the national treatment obligation imposed in Article 5. Article 20 provides that " $[\mathrm{t}]$ he Governments of the countries of the Union reserve the right to enter into special agreements among themselves, in so far as such agreements grant to authors more extensive rights than those granted by the Convention ....."84 The WCT itself is such a special agreement, and it does grant authors more extensive rights than are guaranteed in Berne. Like Berne, the WCT imposes no obligations on parties with respect to their own nationals. Thus, if each party to the WCT granted nationals of other parties, but not its own nationals, the rights that the WCT guaranteed, then the Berne Convention would not require extension of those rights to nationals of countries that were Berne Union members but not WCT parties. In practice, however, WCT parties do grant the rights guaranteed by the WCT to their own nationals. Once they do that, the national treatment guarantee of Berne steps in, and requires them to extend the same rights to nationals of all Berne Union members, even if they are not WCT parties. In addition, the most favored nation obligation of TRIPS Article 4 would require WTO members to extend any rights granted to the nationals of one other member to those of all other members even if they did not grant those rights to their own nationals. ${ }^{85}$

In practice, this set of circumstances would seem to be one of the reasons why the United States has been pursuing so-called "TRIPS-plus" copyright protections in free trade agreements, rather than bilateral copyright treaties. Once the United States has granted additional rights either to its own nationals or to the nationals of any other WTO member, it cannot use those rights as a bargaining chip in negotiations requesting reciprocity; it must grant those rights to nationals of all other WTO members. By contrast, Article XXIV(5) of GATT specifically exempts free trade agreements meeting certain conditions from both the national treatment and most favored nation obligations, ${ }^{86}$ and hence the United States can use the enticement of lower trade barriers with regard to goods to induce both reciprocal trade barrier reductions and higher copyright protection.

The areas of controversy over the definition of "rights" for purposes of Berne Convention national treatment have concerned various laws that provide payments to

\footnotetext{
${ }^{81}$ See, e.g., Robertson Davies, The Fifth Business.

${ }^{82}$ See, e.g., Arundhati Roy, The God of Small Things.

${ }^{83}$ See Jane C. Ginsburg, The (New?) Right of Making Available to the Public, in Intellectual Property in the New Millennium, Essays in Honor of William R. Cornish 234 (David Vaver \& Lionel Bently, eds. 2004) ("Berne Convention members who have not yet ratified the WCT are not obliged to enforce foreign Berne Union authors' rights of making available (unless that country's own authors enjoy such a right, in which case the principle of national treatment would require extending the same protection to Unionist authors).").

${ }^{84}$ Berne Convention Art. 20.

${ }^{85}$ See TRIPS Art. 4.

${ }^{86}$ See General Agreement on Tariffs and Trade 1947 Art. XXIV(5); Understanding on the Interpretation of Article XXIV of the General Agreement on Tariffs and Trade 1994.
} 
authors rather than grant exclusive rights. These include schemes such as private copying levies, public lending rights, and droit de suite laws. How do we determine whether such schemes grant rights that are subject to the national treatment obligation? Paul Goldstein, building on previous work by Elisabeth Steup ${ }^{87}$ and Peter F. Burger ${ }^{88}$ has suggested that there are three elements that constitute an economic right subject to Berne national treatment.

First, such a right is "effective against the world at large." ${ }^{89}$ This distinguishes copyright from mere contractual rights.

Second, a Berne right "enables the author to control, or to benefit from, the use of a literary work." that the Berne Convention grants are rights of authors to particular works. Thus, rights that authors might have independent of particular works, such as rights to various subsidies or pensions, would not count as Berne rights that trigger a national treatment obligation. Moreover, a right "to benefit fro[m] the use of a literary work" would seem to require that payment is being made at least roughly by users of the work. Suppose that a government is funding a scheme of subsidies to authors from general tax revenues, and that it distributes those subsidies in proportion to the revenues the authors have received from sales of their works. Would the restriction of those subsidies to authors who are nationals of that country violate the Berne national treatment obligation? While other WTO treaties do regulate subsidies with regard to goods in industries such as agriculture ${ }^{91}$ and manufacturing, ${ }^{92}$ and embody a commitment to negotiate limitations on subsidies with regard to services, ${ }^{93}$ neither the Berne Convention nor TRIPS purport to regulate general government subsidies to authors. Thus a subsidy to national authors from general tax revenues should not

${ }^{87}$ See Elisabeth Steup, The Rule of National Treatment for Foreigners and its Application to New Benefits for Authors, 25 Bull. Copr. Soc'y 279, 284 (1978). Steup defines as the essential elements of copyright protection that the right be granted "to (1) a person in his capacity as author (2) of a determined work, and, (3) the right being related to the utilization of that work." Id.

${ }^{88}$ See Peter F. Burger, The New Photocopy Remuneration Provisions in the Federal Republic of Germany and Their Application to Foreign Authors under International Copyright Law, 19 I.I.C. 488, 500-501 (1988).

${ }^{89}$ Paul Goldstein, International Copyright: Principles, Law, and Practice $\$ 3.2 .3 .1$ at 81 (2001).

${ }^{90} \mathrm{Id}$.

${ }^{91}$ See Agreement on Agriculure, Apr. 15, 1994, Marrakesh Agreement Establishing the World Trade Organization, Annex 1A, 1867 U.N.T.S. 410, Art. 6 (domestic support commitments), Art. 9 (export subsidy commitments).

${ }^{92}$ See GATT 1947 Art. XVI (subsidies); Agreement on Subsidies and Countervailing Measures, Apr. 15, 1994, Marrakesh Agreement Establishing the World Trade Organization, Annex 1A, 1867 U.N.T.S. 14, Art. 3 (certain subsidies in both agriculture and manufacturing).

${ }^{93}$ See General Agreement on Trade in Services, Apr. 15, 1994, Marrakesh Agreement Establishing the World Trade Organization, Annex 1B, 1869 U.N.T.S. 183, 33 I.L.M. 1167 (1994), Art. XV. 
count as a violation of the Berne or TRIPS national treatment obligations. ${ }^{94}$ Yet neither should Berne rights be restricted to compensation that is derived from "a particular use by a particular user." ${ }^{.95}$ After all, even compensation tied to the making of a copy - the quintessential author's right of reproduction - is not compensation derived from a particular use by a particular user, since copies can be used by many for many different purposes, and resold many times, and the value of the copy on first sale typically reflects that multiplicity of possible uses and users.

Third, a Berne right "values the use of the work, however roughly, proportionate to the work's success or prospective success in the marketplace." ${ }^{.96}$ This third element is in some ways a further unpacking of the second element, detailing just what it means to be a right connected with a work, not just with authorship. Just as payments approximating an exclusive right must at least in some rough way come from users of works, they must also be distributed to authors or copyright owners roughly in proportion to the frequency of use of their works.

Schemes that satisfy all three of these conditions do not just look similar to Berne exclusive rights; they also have a similar political or public choice profile. A scheme providing benefits to authors that is funded by general tax revenues must compete with other objects of legislative desire in the appropriations process. By contrast, a separate levy on users isolates the scheme from such competition. A levy on the use of copyrighted works the proceeds of which are used for general cultural purposes will draw the critical scrutiny of domestic authors, who will view it as reducing demand and redistributing away from successful works. By contrast, a levy on the use of all works the proceeds of which are distributed to authors of domestic works in proportion to their success accomplishes a redistribution from foreign authors to domestic authors, and will be welcomed by the latter, leaving the interests of foreign authors to be represented only by diffuse groups of users.

Consider the application of this three-element definition of a Berne right to four different types of remuneration schemes.

a. Public lending payments. Most public lending subsidies are funded through general tax revenues, rather than by fees specifically assessed with respect to books lent. According to the Public Lending Right International Network, the Netherlands and Luxembourg fund their public lending payments through fees paid by libraries, ${ }^{97}$ and France funds its payments in part through fees paid by suppliers of books to

\footnotetext{
${ }^{94}$ For a contrary view, see Committee of Experts on a Possible Protocol to the Berne Convention, Third Session, BCP/CE/III/2-III, I 87, at 26 (1993).

${ }^{95}$ David Vaver, The National Treatment Requirements of the Berne and Universal Copyright Conventions Part Two, 17 I.I.C. 715, 718 (1986) ("The author would have a 'right' against [a home taping fund funded by levies on home taping hardware or software] but it would not be in respect of a particular use by a particular user, any more than paying the proceeds of a tax levied on the manufacturers of handguns to the victims of gun crimes would be considered a victim's right against gun manufacturers.").

${ }^{96}$ Paul Goldstein, International Copyright: Principles, Law, and Practice $\$$ 3.2.3.1 at 81 (2001).

97 See PLR Systems Around the World: Some Basic Facts, http://www.plrinternational.com/plraroundtheworld.pdf.
} 
libraries. $^{98}$ All other governments with existing public lending schemes fund them from general tax revenues. ${ }^{99}$ Thus, the fact that only citizens of Israel writing in Hebrew or Arabic are eligible for payments under the Israeli public lending scheme, ${ }^{100}$ or that only Hungarian authors and foreign authors under reciprocal agreements are eligible under the Hungarian scheme, ${ }^{101}$ should not violate the national treatment obligations of Berne or TRIPS. Yet the fact that the Luxembourg scheme, funded by fees assessed to libraries and distributed to authors in accordance with the number of times their books are lent, is limited to authors who are residents of Luxembourg, ${ }^{102}$ should raise serious doubts about whether it is violation of Luxembourg's national treatment obligation under Berne and TRIPS. ${ }^{103}$

$b$. The French motion picture subsidy system. France subsidizes production of French films with funds collected almost entirely from three special taxes: a tax on movie theatre tickets, a tax on television broadcasting, and a tax on the sale of videos. ${ }^{104}$ All three of the taxes are more in the nature of targeted user fees than general income or sales taxes. For example, the tax on movie theatre tickets, known as the "Taxe sur le prix des entreés en salles" or "Taxe Spécielle Additionelle" (TSA), is imposed at the rate of $10.7 \%$ of the price of each movie theatre ticket. ${ }^{105}$ There is no question that foreign movies are generating revenues under this system. In 2010, for example, $47.5 \%$ of all movie tickets sold in France were to movies made in the United States, and $16.7 \%$ to movies made in other countries outside of France, while only $35.7 \%$ of admissions were to movies made in France. ${ }^{106}$ The funds generated by these taxes, however, are used to subsidize only certain films. Movie production companies

${ }^{98}$ See id.

${ }^{99}$ See id.

${ }^{100}$ See id.

${ }^{101}$ See id.

${ }^{102}$ See id

${ }^{103}$ In testimony before a committee of the United States House of Representatives in 1993, Mihály Ficsor, then Director of the Copyright Department of WIPO, concluded that the public lending right concerning books and similar publications was a "de facto" exception to national treatment, "because it relates to an act that traditionally has not been considered to be part of the normal exploitation of works and whose source is quite exceptional in the field of copyright, namely, in the majority of cases, the budget of the government or the municipalities concerned." Prepared Statement of Mihály Ficsor, Director, Copyright Department, World Intellectual Property Organization (WIPO), Geneva, Switzerland, in A Possible Protocol to the Berne Convention, Hearings Before the Subcommittee on Intellectual Property and Judicial Administration of the Committee on the Judiciary, House of Representatives, $103^{\text {rd }}$ Cong., $1^{\text {st }}$ Sess., Serial No. 35, at 55, 61.

${ }^{104}$ See generally Emmanuel Cocq and Patrick Messerlin, French Audio-Visual Policy: Impact and Compatibility with Trade Negotiations, HWWA Report No. 233, available at http://ageconsearch.umn.edu/bitstream/26105/1/re030233.pdf.

105 See Ministère de la Culture et de la Communications, Chiffres Clés 2012 Satistiques de La Culture: Cinéma, available at http://www.culturecommunication.gouv.fr/Politiques-ministerielles/Etudes-etstatistiques/Les-publications/Chiffres-cles-statistiques-de-la-culture/Chiffres-cles2012-Statistiques-de-la-culture.

${ }^{106}$ See id. 
that are "established outside Europe" are disqualified altogether from receiving subsidies, and movies otherwise must amass a certain minimum number of qualifying points, which are awarded for such characteristics as hiring French actors or workers and the use of the French language in the film. ${ }^{107}$ The discrimination is thus in part de jure (the exclusion of non-European production companies) and part de facto (the use of qualifying characteristics that closely correlate with French authorship), and would seem to violate Berne and TRIPS national treatment obligations if they applied.

There is a good argument that the national treatment obligations do apply, at least as to a portion of the subsidies. About half of the subsidies are awarded as "soutiens sélectifs," or discretionary support, while the other half is spent on "aides automatiques," automatic aid. ${ }^{108}$ Since 1989, automatic aid has been granted on the basis of a percentage of total receipts generated by a qualifying movie, including receipts from theatrical exhibition, television broadcast, and video sales. That formula thus tracks market success, satisfying Paul Goldstein's third element of a Berne right. ${ }^{109}$ At least in part, then, the French system pretty clearly magnifies the market success of French films, while blunting the market success of non-French films, violating the Berne and TRIPS national treatment obligations.

c. Private copying levies. Many countries have instituted levies on equipment that can make copies of works of authorship (as well as of productions protected by related rights), from photocopiers to audio and video equipment, and on blank media from paper to magnetic tape and optical disks, with the purpose of recouping some of the value lost to owners of copyright from private copying. These levies are typically paired with copyright exceptions for private copying, and those exceptions can raise issues, not only of national treatment, but of the right of reproduction specifically guaranteed by Berne,${ }^{110}$ and of the "three-step tests" for exceptions under both Berne $e^{111}$ and TRIPS. ${ }^{112}$ Considering just the issue of national treatment, however, the levies themselves are not general income or sales taxes, but use-related levies that should satisfy the criterion of being closely enough derived from users of a work. Indeed, in the European Union, the well-known Padawan case has had the effect of more tightly focusing levies on equipment that is actually used for private copying. ${ }^{113}$ Thus, the

${ }^{107}$ See Emmanuel Cocq and Patrick Messerlin, supra n. 89, at 10.

${ }^{108}$ See Centre National du Cinéma et de l'Image Animée, Rapport D’Activité 2011 du Centre National du Cinéma et de l'Image Animée 13 (2012), available at http://www.cnc.fr/web/fr/publications/-

/ressources/2437585;jsessionid=DB42D069ED9E9BAEAE62F2497CC79482.liferay.

${ }^{109}$ See suprap.xx.

${ }^{110}$ See Berne Convention Art. 9(1). For a discussion of how private copying provisions may implicate Berne substantive minima, see I Ricketson \& Ginsburg $\$ 6.97$, at 317318.

${ }^{1111}$ See Berne Convention Art. 9(2).

${ }^{112}$ See TRIPS Art. 13.

${ }^{113}$ See Padawan SL v. Sociedad General de Autores y Editores de Espana (SGAE), (C-467-08), 2010 WL 4116866 (ECJ (2010)) (holding that the indiscriminate application of a private copying levy to all copying equipment, including equipment acquired by business entities for purposes clearly unrelated to private copying, violates Article 5(2)(b) of the "Infosoc Directive," Directive 2001/29/EC of the European Parliament 
crucial issue would seem to be how the funds so collected are distributed. Some countries distribute some or all of the funds so generated, not to authors in some rough proportion to the use of their works, but for local cultural causes more generally. ${ }^{114}$ Other countries, however, do distribute private copying levy funds to authors using some technique of sampling of sales. ${ }^{115}$ In such cases, a private copying levy should be subject to Berne and TRIPS national treatment obligations. ${ }^{116}$ France has justified its refusal to distribute funds from its levy on audiovisual media to US film producers on the ground that it has no agreement with the United States regarding "producers of videograms," yet as several commentators have argued, the works in question are audiovisual works, covered by the Berne Convention and TRIPS and subject to their national treatment obligations. ${ }^{117}$

d. Droits de Suite. A droit de suite or resale right is a limited exception to first sale exhaustion of copyright in the original embodiment of a work, such as a painting or a sculpture. It entitles the artist to a portion of a higher subsequent sale price. Whether droits de suite would be subject to the general Berne Convention national treatment obligation is an interesting question, but in 1948 the Brussels revision of the Convention foreclosed such speculation by adopting a specific provision for droits de suite. Article 14ter provides for a droit de suite, but makes its application subject to material reciprocity. Article 14ter(2) states that the droit de suite "may be claimed in a country of the Union only if legislation in the country to which the author belongs so permits." $" 118$

2. Rights in Performances, Phonograms, and Broadcasts: the Rome Convention, TRIPS, and the WPPT. While the national treatment provisions regarding copyright-protected works in Berne and TRIPS clearly extend beyond the minimum rights granted in those treaties, the national treatment provisions regarding performances, phonograms, and broadcasts are arguably more limited.

Article 2(2) of the Rome Convention provides that "[n]ational treatment shall be subject to the protection specifically guaranteed, and the limitations specifically provided for, in this Convention." That could just mean that even if domestic law provides Rome-mandated national treatment, that law will be further tested to see if it complies with Rome-mandated specific minimum protections, and the limitations thereto. The WIPO Guide to the Rome Convention adopts that interpretation. It states that the import of Article 2(2) is that "[e]ven if a Contracting State does not grant [the] minima [established in Articles 7, 10 and 13] to its own

and of the Council of 22 May 2001 on the harmonisation of certain aspects of copyright and related rights in the information society).

114 See Gillian Davies and Michèle E. Hung, Music and Video Private Copying: An International Survey of the Problem and the Law (1993).

${ }^{115}$ Seeid.

${ }^{116}$ Commentators reaching this conclusion include Sam Ricketson and Jane Ginsburg, see I Ricketson \& Ginsburg $\$$ 6.97, at 618; Paul Goldstein and Bernt Hugenholtz, see Goldstein \& Hugenholtz ( $3^{\text {rd }}$ ed.) 1ll; and Peter Burger, see Peter F. Burger, supra note $\mathrm{xx}$, at 500-501.

${ }^{117}$ See, e.g, II William F. Patry, Copyright Law and Practice 1310-1311 (1994).

${ }^{118}$ Berne Convention Art. 14ter(2). 
nationals, it must do so to nationals of other Contracting States." ${ }^{119}$ Yet others have argued that Article 2(2) limits the national treatment obligation in the Rome Convention to those minimum required protections. ${ }^{120}$ This would not render the Rome national treatment obligation completely meaningless, for the Rome Convention minima leave leeway concerning the form of protection, particularly with respect to performances. Article 7 guarantees performers "the possibility of preventing" certain acts, such as the unauthorized fixation of their performances, but that language was specifically adopted so that both criminal remedies and various forms of civil remedies could satisfy Article 7 requirements. ${ }^{121}$ Thus, even under a limited interpretation, the Rome national treatment obligation would guarantee that if a party granted its nationals civil injunctions and damages for unauthorized fixations of performances, non-nationals would also be entitled to such remedies.

Regardless of the interpretation of the general national treatment provision in the Rome Convention, Article 16 of the Convention allows parties to limit their obligations with respect to the Article 12 right of equitable remuneration for public performances (broadcasts and communications to the public) of phonograms. One of the options is to adopt a requirement of reciprocity, protecting foreign producers of phonograms only to the extent that the countries of which they are nationals protect the phonograms of the nationals of the country adopting reciprocal treatment. ${ }^{122}$ Most of the largest parties to the Rome Convention, including Austria, Belgium, Canada, Denmark, France, Germany, Italy, Japan, the Netherlands, the Russian Federation, and Spain, have made declarations adopting a reciprocal scheme, ${ }^{123}$ thus making reciprocity, rather than national treatment, the dominant regime for public performance of phonograms.

If the national treatment limitations in the Rome Convention are ambiguous, those in TRIPS and the WPPT are not. In the case of related rights, both TRIPS and the WPPT explicitly limit their national treatment obligations (and in the case of TRIPS, its most favored nation obligation) to the particular related rights granted in those respective treaties. ${ }^{124}$ In the case of TRIPS, at least, this may explained in part

119 Claude Masouyé, Guide to the Rome Convention and to the Phonograms Convention I 2.2, at 19 (1981).

${ }^{120}$ See Silke von Lewinski, International Copyright Law and Policy $\$$ 6.27, at 201 and 201 n. 70 (2008).

${ }^{121}$ Rome Convention Art. 7(1); see Claude Masouyé, Guide to the Rome Convention and to the Phonograms Convention II 7.4, 7.5, at 34-35 (1981).

${ }^{122}$ See Rome Convention Art. 16(1)(a)(iv).

${ }^{123}$ See UNESCO, International Convention for the Protection of Performers, Producers of Phonograms and Broadcasting Organizations 1961, Declarations and Reservations, at http://portal.unesco.org/en/ev.phpURL_ID=13645\&URL_DO=DO_TOPIC\&URL_SECTION=201.html \#RESERVES

124 See TRIPS Art. 3(1) ("In respect of performers, producers of phonograms and broadcasting organizations, this [national treatment] obligation only applies in respect of the rights provided under this Agreement."); TRIPS Art. 4(c) (exempting from the most favored nation obligation "any advantage, favour, privilege or immunity accorded ... in respect of the rights of performers, producers of phonograms and broadcasting organizations not provided under this Agreement"); WPPT Art. 4(l) (imposing a national treatment obligation "with regard to the exclusive rights 
by the fact that otherwise, the national treatment and most favored nation obligations could extend to all "related rights," which would be a problem because there is no generally recognized definition for this term. ${ }^{125}$ Yet there is a more pointed history behind these limitations. The US recording industry, in particular, would have liked a stronger national treatment obligation with respect to phonograms, because significant revenues are generated in Europe and elsewhere from both public performance of sound recordings and private copying levies, and if US sound recordings were eligible to receive a portion of those revenues, that portion would be substantial. ${ }^{126}$

In the end, however, the national treatment obligations were limited so as to deny US firms access to public performance revenues, and probably to revenues from private copying levies as well. As for public performances, the national treatment obligation in TRIPS is subject to Rome Convention exceptions, thus allowing countries to make Article 16 declarations adopting a regime of reciprocity. ${ }^{127}$ Similiarly, the WPPT's national treatment obligation is truncated when a party declares that it will not fully implement the right to equitable remuneration for broadcasting and communication to the public. ${ }^{128}$ The US had to make such a declaration, because US law only provides for such a right in the case of digital audio transmissions; ${ }^{129}$ hence, other WPPT parties are under no national treatment obligation with respect to public performances of phonograms not protected by US law. ${ }^{130}$

specifically granted in this Treaty, and to the right to equitable remuneration provided for in Article 15 of this Treaty").

${ }^{125}$ Article 3 of TRIPS generally requires national treatment "with regard to the protection of intellectual property"; "intellectual property" is defined in Article I as "all categories of intellectual property that are the subject of Sections 1 through 7 of Part II," TRIPS Art. I(2), and Section 1 of Part II is titled "Copyright and Related Rights." See Daniel Gervais, The TRIPS Agreement: Drafting History and Analysis $\$ 2.59$, at 198 ( $4^{\text {th }}$ ed. 2012) (advancing this explanation).

${ }^{126}$ See, e.g., Prepared Statement of Jason S. Berman, President, Recording Industry Association of America, in A Possible Protocol to the Berne Convention, Hearings Before the Subcommittee on Intellectual Property and Judicial Administration of the Committee on the Judiciary, House of Representatives, $103^{\text {rd }}$ Cong., $1^{\text {st }}$ Sess., Serial No. 35, at 112-114.

${ }^{127}$ See TRIPS Art. 3(1); supra text accompanying notes 122-123.

${ }^{128}$ See WPPT Art. 4(2) (limiting the national treatment obligation "to the extent that another Contracting Party makes use of the reservations permitted by Article 15(3) of this Treaty"); Art. 15(3) (providing for declarations limiting the obligation to recognize a right of equitable remuneration for broadcasting and communication to the public of phonograms).

129 See 17 U.S.C. $\$$ 106(6) (providing a digital audio transmission right); WPPT Notification No. 8, Ratification by the United States of America, available at http://www.wipo.int/treaties/en/notifications/wppt/treaty_wppt_8.html (containing a declaration limiting implementation of Article 15 to digital audio transmissions).

${ }^{130}$ The North American Free Trade Agreement contains a broader national treatment provision with respect to sound recordings. Its general national treatment obligation extends "to the protection and enforcement of all intellectual property rights"; the specific exception for sound recordings provides for reciprocity for performers' rights in secondary uses, but not for producers' rights in such uses: "In respect of sound 
The situation with respect to private copying levies regarding phonograms is a bit more complicated. If copying is the activity, then the underlying right is the right of reproduction, a right guaranteed to phonogram producers by Article 14(2) of TRIPS $^{131}$ and Article 11 of the WPPT ${ }^{132}$ Thus one could easily imagine an argument that to the extent that national law provides remuneration to phonogram producers for certain types of unauthorized reproduction in lieu of the ability to prevent that reproduction altogether, the national treatment obligation should apply to that remuneration. ${ }^{133}$ The United States, however, tried but failed to get specific guarantees of national treatment with regard to rights of remuneration in both TRIPS and the WPPT. ${ }^{134}$ The drafting history of Article 4 of the WPPT, in particular, suggests that many countries did not want the obligation of national treatment to reach private copying levies or rights of remuneration more generally, and that they thought that the wording of Article 4 as eventually adopted accomplished that objective. $^{135}$ Article 4(1) guarantees national treatment "with regard to the exclusive rights specifically granted in this Treaty, and to the right to equitable remuneration provided for in Article 15 of this Treaty." ${ }^{\prime 136}$ The argument is that limiting the guarantee to "specifically granted exclusive rights" excludes rights of remuneration, since rights of remuneration are not "exclusive rights"; the only right of remuneration covered is the explicitly mentioned right to equitable remuneration for broadcasting and public communication. This argument has been advanced by Jörg Reinbothe and Silke von Lewinski, ${ }^{137}$ and accepted by Sam Ricketson and Jane Ginsburg. ${ }^{138}$

recordings, each Party shall provide such treatment to producers and performers of another Party, except that a Party may limit rights of performers of another Party in respect of secondary uses of sound recordings to those rights its nationals are accorded in the territory of such other Party." North American Free Trade Agreement (Washington, D.C., 12 Dec. 1992), U.S.-Can.-Mex., U.S. Gov't Printing Office (1992), entered into force l Jan. 1994, Art. 1703.

${ }^{131}$ See TRIPS Art. 14(2).

${ }^{132}$ See WPPT Art. 11.

${ }^{133}$ For such an argument, see Andrew F. Christie, John Davidson, and Fiona Rotstein, Canada's Private Copying Levy - Does It Comply with Canada's International Treaty Obligations?, 20 I.P.J. 111, 128-129 (2008); Mihaly Ficsor, The Law of Copyright and the Internet 614 (2002).

${ }^{134}$ With regard to TRIPS, these unsuccessful attempts are mentioned in IV The Gatt Uruguay Round: A Negotiating History (1986-1994) 510-511, 516, 518, 520, 524 (Terence B. Stewart, ed., 1999).

${ }^{135}$ For an account of that history, see Jörg Reinbothe and Silke von Lewinski, The WIPO Treaties 1996, 279-284 (2002). For a U.S. proposal for a broader provision that would guarantee national treatment with respect to "rights which derive from any exclusive right provided in this Treaty, including but not limited to rights of remuneration," see Submission of the United States of America on the New Article 4, SCCR $/ 4 / 3$ (February 2l, 2000) available at http://www.wipo.int/meetings/en/html.jsp?file=/redocs/mdocs/copyright/en/sccr_4/sc cr_4_3.html.

${ }^{136}$ WPPT Art. 4(1). The recently concluded Beijing Treaty on Audiovisual Performances uses the same language to express its national treatment obligation. See Beijing Treaty on Audiovisual Performances, adopted on June 24, 2012, Art. 4(1).

${ }^{137}$ See id. at 287-288. 


\section{National Treatment and Other Dimensions of Protection: Remedies, Acquisition, Term and Ownership}

Although the issues of works or productions protected and rights granted are the most central to the scope of a national treatment obligation in copyright and related rights, those issues do not exhaust the dimensions of protection. How does national treatment operate with regard to such further issues as remedies, acquisition of rights, term of protection, and ownership and transfer of rights?

1. The Berne Convention (and the WCT). Article 5(1) of the Berne Convention (also incorporated by reference in the WCT) refers only to works and rights, and to modern eyes this language might seem not to address other dimensions of protection. It seems more likely, however, that the Berne drafters believed that, subject to the explicit substantive minima and exceptions in the Convention itself, they were accomplishing what Stephen Ladas called "the complete assimilation of foreigners to nationals, without condition of reciprocity."

As for remedies, that expansive view gains support in Article 5(2), which refers to "the means of redress afforded the author to protect his rights" as one of the dimensions left to national law but presumably subject to the national treatment guarantee. ${ }^{140}$ One issue that arises in that regard is how to understand the relation between "the means of redress," left to national law, and "the enjoyment and exercise of" the author's rights, which Article 5(1) prohibits from being "subject to any formality. ${ }^{141}$ US law takes the position that Article 5(1) requires an accommodation in respect of foreign works to enable the filing of lawsuits alleging infringement in them without the formality of registration required for United States works. ${ }^{142}$ However, US law also takes the position that "the exercise of rights" to be kept free of formalities does not extend to the remedies of statutory damages and attorney's fees. The latter are made available only on condition that the infringed work has been registered before the infringement; ${ }^{143}$ following the national treatment obligation, that condition is applied equally to nationals and foreigners. If that tracks the correct interpretation of Articles 5(1) and 5(2), then here the national treatment obligation is doing work where a substantive minimum - the prohibition on formalities - does not apply. ${ }^{144}$

${ }^{138}$ See II Ricketson \& Ginsburg $\$ \$ 19.49,19.50$. Ricketson and Ginsburg seem to be influenced principally by drafting history and perhaps by the specific mention in the WPPT of a single right of remuneration, since with respect to the Berne Convention, they advance the argument that within the scope of applicable exclusive rights, rights of remuneration are tantamount to compulsory licenses. See I Ricketson \& Ginsburg \$ 6.97.

${ }^{139}$ Stephen P. Ladas, The International Protection of Literary and Artistic Property 365 (1938)

${ }_{140}$ Berne Convention Art. 5(2).

${ }^{141}$ Berne Convention Art. 5(1).

${ }^{142}$ See 17 U.S.C. $\$ 411(\mathrm{a})$.

${ }^{143}$ See 17 U.S.C. $\$ 412$. In the case of published works, $\$ 412$ creates a grace period for registration of three months after publication.

${ }^{144}$ At least two copyright owners have attempted to challenge the US Copyright Act's requirement that foreign works have been registered before the claimed infringement to be eligible for statutory damages and attorney's fees, but courts have that because 
Acquisition and term are two dimensions separately covered in Berne. As to the former, the Article 5(2) prohibition on formalities precludes Union members from imposing conditions such as registration or notice on the acquisition of copyright in a work, and Article 2(2) allows Union members only to impose a requirement of fixation as a condition of protection. ${ }^{145}$ As to the latter, Article 7(8) establishes the socalled "Rule of the Shorter Term," respect to term, perhaps the single most important explicit exception to national treatment in the Convention. This exception to national treatment for term, together with the 1993 EU Council Directive's extension of copyright term in Europe to life of the author plus 70 years, was an important motivation for the US to extend its copyright term from life plus 50 years to life plus 70 years in $1998{ }^{147}$

Sierd Schaafsma has argued convincingly that, as an historical matter, the Berne Convention national treatment provision was intended to encompass a choiceof-law rule under which issues of ownership would also be resolved by the law of the country in which protection was sought. ${ }^{148}$ Given vast changes in general approaches to conflicts of laws, ${ }^{149}$ however, it is hard to know how the original understanding of the Convention should be implemented in the present day, and it is clear that some

the Berne Convention is not self-executing in the United States, it is not possible to challenge federal law on the basis of conflict with Berne. See Elsevier B.V. v. UnitedHealth Group, Inc., 2010 WL 150167, *2-*3 (S.D.N.Y. 2010); The Football Ass'n Premiere League Ltd. v. YouTube, Inc., 633 F.Supp.2d 159, 164 (S.D.N.Y. 2009).

${ }^{145}$ See Berne Convention Arts. 5(2), 2(2).

${ }^{146}$ See Berne Convention Art. 7(8).

147 See Council Directive 93/98/EEC of 29 October 1993 Harmonizing the Term of Protection of Copyright and Certain Related Rights, 1993 Official J. Eur. Coms. (L 290), p. 9; Copyright Term Extension Act, Pub. L. 105-298, \$102(b), 112 Stat. 2827 2828; Eldred v. Ashcroft, 537 U.S. 186, 205-206 (2003) (discussing the motivations of Congress).

${ }^{148}$ See Sierd J. Schaafsma, Intellectuele eigendom in het conflictenrecht : de verborgen conflictregel in het beginsel van nationale behandeling (2009). Schaafsma is not the first commentator to advocate a connection between the national treatment provision in Berne and the choice of law principle of lex protectionis. Indeed, Mirelle van Eechoud has argued that this is the majority position among commentators. See Mirelle van Eechoud, Choice of Law in Copyright and Related Rights 106-107 \& 107 n. 300 (2003); compare, e.g., Paul Geller, Conflicts of Laws in Copyright Cases: Infringement and Ownership Issues, 51 J. Copyright Soc'y U.S.A. 315, 328-329 (2004) (Berne national treatment regime includes a lex protectionis choice-of-law rule) with Goldstein \& Hugenholtz ( $3^{\text {rd }}$ ed.) 131 (Berne national treatment is a nondiscrimination principle that does not include a choice-of-law rule). However, Schaafsma explains exactly why this connection followed from the dominant choiceof-law framework of the mid-nineteenth century.

${ }^{149}$ Essentially, this involved a shift from the doctrine of statutes to the "interest" or "center of gravity" approach of Friedrich Carl von Savigny. See Schaafsma, supra note 148. 
courts do not feel bound to decide issues of ownership of foreign works as if they had been produced domestically. ${ }^{150}$

2. TRIPS. Paradoxically, the TRIPS national treatment provision may be seem to list more aspects of protection than the Berne Convention, and yet not quite reach the "complete assimilation" ideal implicitly embodied in the original understanding of Berne. TRIPS guarantees national treatment with respect to "the protection of intellectual property," and "protection" is defined as including "matters affecting the availability, acquisition, scope, maintenance and enforcement of intellectual property rights as well as those matters affecting the use of intellectual property rights specifically addressed in this Agreement" ${ }^{\text {"51 }}$ That is a long and broad list, and yet TRIPS does not include a choice-of-law rule. Thus, it would not seem even arguably to violate TRIPS national treatment to determine ownership through application of the law of the country of origin rather that the country of protection.

3. The Rome Convention and the WPPT. Although this article, consistent with common usage, has been using "national treatment" to describe obligations imposed by all five CRR treaties, neither the Berne Convention, nor the WCT, nor TRIPS use the terms "national treatment" or "treatment" in their operative language. That use is left to the Rome Convention and the WPPT. The Rome Convention obligates parties to provide "the treatment accorded by the domestic law of the Contracting State in which protection is claimed"152 to nationals regarding specified activities occurring in its territory. The WPPT requires each party to "accord to nationals of other Contracting Parties ... the treatment it accords to its own nationals" with regard to covered rights. ${ }^{153}$ The term "treatment" seems quite expansive, evincing the "complete assimilation" spirit of the Berne drafters, when not limited by other provisions in these treaties. While the Rome Convention permits the formality of notice on phonograms, ${ }^{154}$ the WPPT prohibits all formalities along the lines of Berne. ${ }^{155}$ Neither Rome nor the WPPT contains a "rule of the shorter term"; if parties grant terms of protection longer than the required minimums to their nationals, they must grants those terms to the nationals of other parties.

\section{Conclusion}

How much work does national treatment do in the area of copyright and related rights? As warned at the beginning, this article has not provided a comprehensive answer to this question. Rather, it has surveyed major issues of treaty interpretation in those areas, and it has made some anecdotal observations about national laws actually in force and the value of exported and imported works and productions.

${ }^{150}$ See, e.g., Itar-Tass Russian News Agency v. Russian Kurier, Inc., 153 F.3d 82 (2d Cir. 1998) (applying Russian law to determine the ownership of works for which protection was sought against infringement in the United States).

${ }_{51}$ TRIPS Art. 3(1), TRIPS n. 3.

${ }^{152}$ Rome Convention Art. 2.

${ }^{153}$ WPPT Art. 4(1).

${ }^{154}$ See Rome Convention Art. 11.

${ }^{155}$ See WPPT Art. 20. 
As for the form of the national treatment guarantee, potentially the most important development is the incorporation of de facto GATT analysis into TRIPS. However, the practical impact of that analysis in the area of copyright and related rights may be limited, because it may be difficult to identify "like goods" or "like works" with respect to an entire category of works of authorship, such as perfumes or fragrances, that is excluded from copyright protection.

As for works and productions covered, before TRIPS specifically recognized computer programs as literary works, there might have been room for a category of works of great value, unenumerated in Berne, to be protected only by national treatment. At present, however, there does not currently seem to be any category of works of comparable economic value that is not enumerated in Berne or TRIPS. It is unlikely that sound recordings would be found to be Berne-protected works in countries in which they are treated under copyright rather than under a related rights scheme, but if so, national treatment could have a greater role to play.

As for rights covered, the national treatment obligation with respect to rights of remuneration continues to be controversial. Perhaps the principal lesson in this area is that the pressure to deviate from national treatment may be coming, not from economic protectionism, but from cultural preservationism and nurturing of local culture. Stephen Siwek estimates that the revenues flowing into the United States from other countries from the sale of software in 2010 was $\$ 98.60$ billion, which dwarves the foreign revenues from motion pictures ( $\$ 23.89$ billion), sound recordings ( $\$ 6.48$ billion), and books and periodicals ( $\$ 5.05$ billion). ${ }^{156}$ Yet private copying and public lending levies and France's motion picture taxes do not touch software; they are targeted at traditional cultural goods like books, movies, and records, and their unequal treatment of foreigners seems primarily motivated by promotion of local culture, and concerns about domination by the United States and the English language, rather than by worries about the balance of payments.

It is clear that in areas in which national treatment would lead to major imbalances in the scope of protection, such as copyright term or public performance for sound recordings, countries have negotiated exceptions to the national treatment obligation, leaving national treatment to cover rights of less economic consequence. Although national treatment continues to have substantial interstitial force, the greatest value of national treatment in copyright and related rights may be, not the specific economic benefits it provides, but the spirit of internationalism it conveys, and the gentle nudge it provides to legislatures and judges away from petty protectionism. In 1977, Elisabeth Steup remarked that "solutions restricted to national authors will set examples for other national legislatures and initiate a backward development from international protection to nationalism at a time when the international exchange in culture is growing and the international protection of authors is more needed than ever before."157 Over 35 years later, that statement still rings true, and the principle of national treatment still best crystallizes that spirit of internationalism.

\footnotetext{
${ }^{156}$ See Stephen E. Siwek, Copyright Industries in the U.S. Economy: The 2011 Report 17 (2011) (Table A-5).

${ }^{157}$ Elisabeth Steup, The Rule of National Treatment for Foreigners and its Application to New Benefits for Authors, 25 Bull. Copr. Soc'y 279, 290 (1978).
} 